\title{
Leishmania (Leishmania) martiniquensis n. sp. (Kinetoplastida: Trypanosomatidae), description of the parasite responsible for cutaneous leishmaniasis in Martinique Island (French West Indies)
}

\author{
Nicole Desbois ${ }^{1}$, Francine Pratlong ${ }^{2}$, Danièle Quist ${ }^{3}$, and Jean-Pierre Dedet ${ }^{2}$,*
}

${ }^{1}$ CHU de la Martinique, Hôpital Pierre-Zobda-Quitman, Pôle de Biologie de territoire-Pathologie, Unité de Parasitologie-Mycologie, BP 632, 97261 Fort-de-France Cedex, Martinique, France

2 Université Montpellier 1 et CHRU de Montpellier, Centre National de référence des leishmanioses, UMR « MIVEGEC » (CNRS 5290, IRD 224, UM1, UM2), Département de Parasitologie-Mycologie (Professeur Patrick Bastien), 39 avenue Charles Flahault, 34295 Montpellier Cedex 5, France

3 CHU de la Martinique, Hôpital Pierre-Zobda-Quitman, Service de dermatologie, Pôle de Médecine-Spécialités médicales, BP 632, 97261 Fort-de-France Cedex, Martinique, France

Received 21 November 2013, Accepted 19 February 2014, Published online 14 March 2014

\begin{abstract}
The parasite responsible for autochthonous cutaneous leishmaniasis in Martinique island (French West Indies) was first isolated in 1995; its taxonomical position was established only in 2002, but it remained unnamed. In the present paper, the authors name this parasite Leishmania (Leishmania) martiniquensis Desbois, Pratlong \& Dedet n. sp. and describe the type strain of this taxon, including its biological characteristics, biochemical and molecular identification, and pathogenicity. This parasite, clearly distinct from all other Euleishmania, and placed at the base of the Leishmania phylogenetic tree, is included in the subgenus Leishmania.
\end{abstract}

Key words: Leishmania martiniquensis n. sp., Cutaneous leishmaniasis, Martinique Island, French West Indies.

Résumé - Leishmania (Leishmania) martiniquensis n. sp. (Kinetoplastida : Trypanosomatidae), description du parasite responsable de la leishmaniose cutanée en Martinique (Antilles Françaises). Le parasite responsable de la leishmaniose cutanée autochtone de Martinique (Antilles françaises) fut isolé pour la première fois en 1995, mais sa position taxonomique n'a été décrite qu'en 2002, bien qu'il ne soit pas nommé à cette époque. L'objet de cet article est de nommer ce parasite Leishmania (Leishmania) matiniquensis Desbois, Pratlong \& Dedet $\mathrm{n}$. sp. et de décrire les caractères biologiques, l'identification biochimique et moléculaire et le pouvoir pathogène de la souche type. Ce parasite, distinct de toutes les autres Euleishmania et placé à la base de l'arbre phylogénétique des Leishmania, est rangé dans le sous-genre Leishmania.

\section{Introduction}

Leishmaniasis is a vector-borne parasitic disease caused by Protozoa of the genus Leishmania, of worldwide distribution. In the New World, it is endemic from Mexico in the North to Argentina in the South [13]. Sporadic cases have been reported in the Caribbean area, particularly in Trinidad [12] and the Dominican Republic [1]. In Martinique Island, occasional autochthonous cases of cutaneous leishmaniasis (CL)-like infections were reported in 1917 [11] and 1951 [7]. More recently, two new cases were reported with isolation of the parasites, and identified by isoenzyme electrophoresis as monoxenous trypanosomatids $[2,5]$. The taxonomical level of the parasites responsible for these two cases (MAR1 and MAR2) was determined by isoenzyme analysis and sequencing of the $18 \mathrm{~S}$ ribosomal RNA gene, as well as partial sequencing of

Nicole Desbois - urn:lsid:zoobank.org:author:BAC8E947-7E42-49ED-B8F0-067DB98A9FFB

Francine Pratlong - urn:1sid:zoobank.org:author:64A32660-5357-4057-9B39-6D72FA859DEA

Danièle Quist - urn:lsid:zoobank.org:author:73354A1E-BB12-4387-8D5B-88C1C4B498D0

Jean-Pierre Dedet - urn:lsid:zoobank.org:author:7ED189EF-9AFD-4A78-A59E-DF4AB24616E5

*Corresponding author: parasito@univ-montpl.fr 
the DNA polymerase alpha and RNA polymerase II largest subunit genes [10]. This study led these authors to consider these parasites as belonging to the genus Leishmania, closely related to the L. (Leishmania) subgenus, and located at the base of all other Euleishmania [10].

A systematic surveillance of cutaneous lesions in Martinique led to the diagnosis of four new cases between 2004 and 2008 (N. Desbois, unpublished data), the molecular and/ or isoenzyme identification of the corresponding parasites showing identity with MAR1 and MAR2.

Therefore, an endemic focus of CL is present in Martinique, due to a well-established Leishmania parasite, with a divergent taxonomic position, apart from any other existing taxa. Since the name Leishmania americana given by Stevenel in his 1917 paper [11] was lacking a description or a definition, we consider it as a nomen nudum, and therefore propose to name this new Leishmania taxon and describe its main features.

\section{Leishmania (Leishmania) martiniquensis Desbois, Pratlong \& Dedet}

urn:lsid:zoobank.org:act:7FB7B26A-3329-44F4-98392A3E8AE38324 1976.

Class: Kinetoplastea Honigberg, 1963 emend. Vickerman, 1952

Order: Trypanosomatida Kent, 1880 stat. nov. Hollande

Family: Trypanosomatidae Doflein, 1951

Authorship: Note that the authors of the new taxon are different from the authors of this paper; Article 50.1 and Recommendation $50 \mathrm{~A}$ of the International Code of Zoological Nomenclature [9].

Strain designation: MHOM/MQ/92/MAR1.

Generic assignment: Amastigotes and promastigotes are the observed morphotypes of this species, which is thereby assigned to the genus Leishmania Ross 1903.

Amastigote measurements: diameter: $3.99 \pm 0.48 \mu \mathrm{m}$.

Promastigote measurements: body length: $9.44 \pm 3.02 \mu \mathrm{m}$; body width: $2.20 \pm 0.63 \mu \mathrm{m}$; flagellum length: $11.59 \pm 3.63 \mu \mathrm{m}$.

Growth in vitro:

- Isolation from biopsy material in Schneider's medium (Serva) supplemented with $10 \%$ foetal calf serum, promastigotes obtained in 4-5 days;

- Culture: difficult to grow, doubling time $24 \mathrm{~h}$ on SDM79 medium (PAA Laboratories GmbH, Austria) supplemented with $15 \%$ foetal calf serum (Invitrogen-Life Technologies, UK - South American origin), $7 \mu \mathrm{g} / \mathrm{mL}$ hemin (SigmaAldrich, USA) and $2.5 \mu \mathrm{g} / \mathrm{mL}$ 6-biopterin (Sigma-Aldrich, USA).

Species assignment: The new species was identified by molecular and isoenzymatic techniques, showing a parasite clearly distinct from all other Euleishmania species and placed at the base of the phylogenetic tree, in the subgenus Leishmania.

Molecular typing: GenBank accession numbers: RNA polymerase AF 326982 and DNA polymerase AF 326983 [10], 18S rRNA AF 303938.
Enzyme profiles: $\mathrm{MDH}^{150}, \mathrm{ME}^{45}, \mathrm{ICD}^{95}, \mathrm{PGD}^{87}, \mathrm{G}^{6} \mathrm{PD}^{78}$, $\mathrm{GLUD}^{300}, \mathrm{DIA}^{30}, \mathrm{NP}^{00}, \mathrm{NP}^{85}, \mathrm{GOT}^{170}{ }^{17}, \mathrm{GOT}^{00}, \mathrm{PGM}^{104}$, $\mathrm{FH}^{65}, \mathrm{MPI}^{13}, \mathrm{GPI}^{52}$, corresponding to zymodeme MON-229.

Type host: man.

Locality in host: skin.

Pathology in man: multiple nodular skin lesions of diffuse cutaneous leishmaniasis pattern, in a patient infected with human immunodeficiency virus (HIV).

Experimental pathogenicity in the murine model: strain infective to BALB/c mice and capable of visceralisation and dissemination in the popliteal and mesenteric lymph nodes, liver, spleen and even brain [8].

Type locality: Martinique island (French West Indies).

Suspected sandfly vector: Unknown

Reservoir(s): Unkown

Type material: Cryopreserved promastigotes were deposited in the Biological Resources Centre of Leishmania in Montpellier, France (BRC-Leish, International Cryobank and Identification Centre for Leishmania, Hospital University Centre and Université Montpellier 1: http://www.parasitologie.univmontp1.fr/english_vers/en_cryobanque.htm, and http://www. fbrcmi.fr/?page_id=14\&lang=en

Homologous strains: Cryostabilates of four strains, belonging to the same zymodeme MON-229, and isolated in various localities of Martinique Island: MHOM/MQ/97/MAR2, MHOM/MQ/2004/MAR7, MHOM/MQ/2007/MAR12 and MHOM/MQ/2008/MAR16

Etymology: The species name is a Latin-like word related to the name of the island where this species is endemic and up to now only located.

\section{Discussion}

An endemic focus of cutaneous leishmaniasis has been known in Martinique Island since 1917, but the parasite responsible was clearly identified as a Leishmania by molecular and isoenzymatic techniques only in 2002 [10]; the taxonomic position of this parasite has already been described: it was clearly distinct from all other Euleishmania, placed at the base of the phylogenetic tree, in the subgenus Leishmania. We therefore propose to name this parasite Leishmania (Leishmania) martiniquensis, Desbois, Pratlong \& Dedet n. sp.

Since the isolation of the type strain in 1992, the four other strains isolated caused cutaneous lesions, the clinical description of which can be summarised as follows: single lesion of the face, of papulo-nodular type, with or without ulceration, sometimes mimicking a basocellular carcinoma. The lesions were localised to the periorbital area, one to the forehead and the last on the ear lobe. Their evolution was spontaneously favourable over several months.

Apart from the princeps case of 1992, which caused a diffuse $\mathrm{CL}$ in an immunocompromised patient, the four other cases corresponded to localised CL in immunocompetent patients. The clinical polymorphism of the localised lesions in immunocompetent patients, and the diffuse lesions in the 
immunocompromised one are not specific to this new species, but similar to clinical features of CL due to other Leishmania species [4].

From an epidemiological point of view, the L. martiniquensis focus appears to be endemic in Martinique Island, with occurrence of rare human cases. The existence of an animal reservoir is highly likely, the candidate reservoirs being one of the wild rodents or marsupials present in Martinique, such as black rats (found infected in Costa Rica by Zeledon in 1992 [14]) or opossums (reservoir hosts in French Guiana [3]). Recent entomological surveys carried out in Martinique Island confirmed the presence of Lutzomyia atroclavata, isolated for the first time in 1966 in Martinique [6] and reported the presence of a second phlebotomine sandfly species: Lutzomyia cayennensis (Desbois N., unpublished).

\section{Conclusion}

At the time of writing, the parasite presently described has never been found outside of Martinique Island. The geographical isolation of this parasite in Martinique might explain its maintenance as an ancestral Leishmania. It remains to determine its vector(s) and reservoir host(s), and to explain why this parasite has not extended to neighbouring countries in the Caribbean area.

Acknowledgements. The authors thank Pr. Patrick Bastien for fruitful discussion and revision of the manuscript, Dr. Christophe Ravel for sequencing of the $18 \mathrm{~S}$ ribosomal RNA genes and fruitful discussion of the paper, Yves Balard for the management of the Leishmania collection database and Patrick Lami and Loic Talignani for expert technical assistance. They also acknowledge Dr. Brigitte Roche for her determining role in the first isolation of the parasite (MAR1). The National Reference Centre for Leishmaniases and the BRCLeish received financial support from the Institut National de Veille Sanitaire (Paris).

\section{References}

1. Bogaert-Diaz H, Rojas RF, de Leon A, de Martinez D, de Quinones M. 1975. Leishmaniasis tegumentaria americana: reporte de primeros tres casos descubiertos en R.D. Revista Dominicana de Dermatologia, 9, 19-31.

2. Boisseau-Garsaud AM, Cales-Quist D, Desbois N, Jouannelle J, Jouannelle A, Pratlong F, Dedet JP. 2000. A new case of cutaneous infection by a presumed monoxenous trypanosomatid in the island of Martinique (French West Indies). Transactions of the Royal Society of Tropical Medicine and Hygiene, 94, 5152.

3. Dedet JP, Gay F, Chatenet G. 1989. Isolation of Leishmania species from wild mammals in French Guiana. Transactions of the Royal Society of Tropical Medicine and Hygiene, 83, 613615.

4. Dedet JP, Pratlong F. 2009. Leishmaniasis, in Cook GC, Zumla AI, Editors. Manson's Tropical Diseases, 22nd ed., Saunders Elsevier: London.

5. Dedet JP, Roche B, Pratlong F, Cales-Quist D, Jouannelle J, Benichou JC, Huerre M. 1995. Diffuse cutaneous infection caused by a presumed monoxenous trypanosomatid in a patient infected with HIV. Transactions of the Royal Society of Tropical Medicine and Hygiene, 89, 644-646.

6. Fauran P, Courmes E, Mille R. 1966. Note sur la présence en Martinique de Phlebotomus atroclavatus (Diptera : Psychodidae). Bulletin de la Société de Pathologie Exotique, 59, 904908.

7. Fouche V, Montestruc L. 1951. Un cas de leishmaniose américaine cutanée. Archives de l'Institut Pasteur de la Martinique, 4, 12-13.

8. Garin YJF, Sulahian A, Meneceur P, Pratlong F, Prina E, Gangneux JP, Dedet JP, Derouin F. 2001. Experimental pathogenicity of a presumed monoxenous trypanosomatid isolated from humans in a murine model. Journal of Eukaryotic Microbiology, 48, 170-176.

9. International Code of Zoological Nomenclature. 1999. The International Trust for Zoological Nomenclature, London, http:// www.nhm.ac.uk/hosted-sites/iczn/code/ accessed on 5th December 2013.

10. Noyes H, Pratlong F, Chance M, Ellis J, Lanotte G, Dedet JP. 2002. A previously unclassified trypanosomatid responsible for human cutaneous lesions in Martinique (French West Indies) is the most divergent member of the genus Leishmania ss. Parasitology, 124, 17-24.

11. Stevenel L. 1917. Présence à la Martinique d'ulcérations de la peau dues à Leishmania americana. Bulletin de la Société de Pathologie Exotique, 10, 379-381.

12. Tikasingh ES. 1974. Enzootic rodent leishmaniasis in Trinidad, West Indies. Bulletin of the Pan-American Health Organization, $8,232-242$.

13. WHO. 2010. Control of the leishmaniasis, Report of a meeting of the WHO expert committee on the control of leishmaniasis. Technical Report series n ${ }^{\circ}$ 949. Geneva, 186 p.

14. Zeledon R. 1992. Leishmaniasis in the Caribbean Islands. A review. Annals of the New York Academy of Sciences, 653, 154-160.

Cite this article as: Desbois N, Pratlong F, Quist D \& Dedet J: Leishmania (Leishmania) martiniquensis n. sp. (Kinetoplastida: Trypanosomatidae), description of the parasite responsible for cutaneous leishmaniasis in Martinique Island (French West Indies). Parasite, 2014, 21, 12. 
N. Desbois et al.: Parasite 2014, 21, 12

\section{- PARASTE}

An international open-access, peer-reviewed, online journal publishing high quality papers on all aspects of human and animal parasitology

Reviews, articles and short notes may be submitted. Fields include, but are not limited to: general, medical and veterinary parasitology; morphology, including ultrastructure; parasite systematics, including entomology, acarology, helminthology and protistology, and molecular analyses; molecular biology and biochemistry; immunology of parasitic diseases; host-parasite relationships; ecology and life history of parasites; epidemiology; therapeutics; new diagnostic tools.

All papers in Parasite are published in English. Manuscripts should have a broad interest and must not have been published or submitted elsewhere. No limit is imposed on the length of manuscripts.

Parasite (open-access) continues Parasite (print and online editions, 1994-2012) and Annales de Parasitologie Humaine et Comparée (1923-1993) and is the official journal of the Société Française de Parasitologie. 